\title{
THE ENERGETIC POTENTIAL OF SPEECH PAUSES
}

\author{
Alla Kalyta \\ National Technical University of Ukraine “Igor Sikorsky Kyiv Polytechnic Institute”, Kyiv, Ukraine \\ kalitanewadd@gmail.com
}

\begin{abstract}
In the paper on the basis of a systemic methodological approach within the framework of speech energetic theory the author advances a theoretical insight into the nature of psycho-energetic generation and decoding of speech pauses in communication as well as offers a theoretical and conceptual solution to the problem of defining the dimensionless criterion able to quantitatively evaluate the levels of emotional and pragmatic potentials of certain speech segments at their pausal juncture, or boundary, termed in the paper as "a pausal jump". The paper elaborates the formula defining the criterion of specific pausal jump of emotional and pragmatic potentials of the adjacent speech segments, being derived on the basis of the substantiated conceptual assumptions and methodological conditions. The author comes to the conclusion that the offered quantitative criterion will (1) advance the possibility to classify the energetic properties of emotional utterances, and (2) will allow the researcher to make up the speakers' typical psycho-energetic portraits.
\end{abstract}

Keywords: speech pauses; speech energetic theory; pausal jump; criterion; emotional-and-pragmatic potential; psycho-energetic generation and decoding; speaker's consciousness, subconscious and unconscious; emotional utterances.

\section{Introduction}

In the spotlight of speech energetic theory, which we are currently working at, the ability of speech pauses to concentrate the utterance's communicative energetic potential became quite evident. Within the very phenomenon of speech pauses we have noticed its double-levelled paradoxical nature. On the one hand, being a physical absence of phonation, the pause is able to produce a powerful subliminal influence on the listener by exciting his/her cognitive processes. On the other hand, being accompanied by paralinguistic means, it often enables the listener to decode a thought not expressed aloud by the speaker. Moreover, the pause is able to start up a sort of dual-technology processes of decoding utterance meaning. According to the first variant of its decoding, the pause in combination with intonation means emphasises the meaning of what was said, thus enhancing its semantic unambiguity. As to the second variant, while allowing the listener to alternatively decode the utterance meaning, the pause releases, so to say, his/her thinking, which, however, can also be limited by the meaning of the following utterances. The assumption can be made that all known tactics of speech pauses' subliminal stimuli on the recipient are based on the variability of combinations of these two contradictory technologies of pauses' interaction.

In addition, we cannot ignore the opinions of noted linguists, psychologists and philosophers on the crucial importance of emotions, $90 \%$ of whose energy is realised by non-verbal means of communication, including the unique role of pauses in oral discourse. Considering all stated above, we have faced the necessity of conducting a conceptual analysis of the energetic essence of speech pauses, determining their emotional and pragmatic potentials as well as mechanisms of dialectically contradictory mutual interaction of both pauses' and utterance's emotional and pragmatic potentials (presented below as EPP) in the processes of speech generation and decoding. The essence of this potential is that during the process of an utterance's actualisation it remains unchanged and is characterised by a stochastic redistribution of energy between the individual's logical and emotional beginnings in such a way that the pragmatic potential is directed at the formation of intentions and the choice of the lexical and grammatical means of expression, while the emotional potential is directed at phonetic and paralinguistic means, thus, completing the utterance's actualisation (Kalyta, 2015, p. 324).

Therefore, the aim of the undertaken study is a theoretical insight into the nature of psycho-energetic generation and decoding of speech pauses in communication as well as a theoretical and conceptual solution to the problem of defining the dimensionless criterion able to quantitatively evaluate the levels of emotional and pragmatic potentials of certain speech segments at their pausal juncture, or boundary (termed in the paper as "a pausal jump").

\section{Methodological stipulations for the study of pauses' energetic potential}

\subsection{The review of scientific ideas about the pause as one of the most unique speech phenomena}

Before solving the stated problem, we are to consider the scientific ideas on the pause as one of the most unique speech phenomena. It follows from the most famous definitions of speech pauses that they are in fact a break in phonation (see, e.g., Jarceva, 1998, p. 369), or silence (Viola \& Madureira, 2008, p. 721). Pauses, being one of the intonation means organising the speech flow, single out intonation groups / syntagms 
through their pitch fluctuations (Kalyta, 2001, p. 128) or abrupt increase of F0 as well as the alteration of voice quality (Viola \& Madureira, 2008, p. 721). Besides, its physical essence is the lack of sound, generated by a stop in the work of speech organs (Jarceva, 1998, p. 369).

Unlike the stops within a word (as in the case of voiceless occlusive consonants production), pauses between words can perform the following functions: 1) delimitative function, i.e. segmenting the speech flow into intonation and semantic units (pauses perform this function in combination with the changes in pitch, intensity and rate of speech; besides, abrupt changes in the latter may substitute a pause); 2) expressive function, which reflects the nature of relationship between the utterance's intonation groups; 3) emphatic function that realises semantic and emotional emphasis of the word or syntagm (Jarceva, 1998, p. 369).

There are a number of other functions of pauses, such as: semantic, syntactic (as a means of delimitation and integration), actualising (as a means of functional sentence perspective), pragmatic (as a means of speakers' interaction), speech planning function (as a means of getting ready for the following utterance), physiological (as a means of breath regulation) (Selivanova, 2010, p. 539), as well as information processing (improve the intelligibility of a sentence) (Gooskens \& Bezooijen, 2014, p. 97). According to Yang (2004), "pauses in conversation function as interactive signals of the turn-taking and suggested topic direction and are also used as expressive elements in discourse, especially for emphasis or dramatic effect and for building up tension and climax. This effect was particularly strong for the storyteller in his narrative, and often acted as a punctuated sequence of emphasised points, where the use of pauses for rhythmic effect is particularly prominent" (p. 270).

The known views of linguists and masters of theatrical art on the pauses' general communicative role can be summarised in the following way. Stanislavski (1959) regards the pause as the most important speech element or tool and as one of "its main trump cards" (p. 87). Besides, it is the pause that regulates the meaning of speech and its intonation organisation, thereby increasing the wealth of all sorts of connotations, emphases, omissions, etc. (Lunacharskij, 1934, p. 480).

Since each pause contains a hidden meaning (Stanislavski, 1959, p. 71), while the very silence belongs to a virtual field of language, the choice between speech and non-speech is defined as a hidden act of speech (Arutjunova, 2000, p. 418). It is apparently not accidental that a special attention is given to the fact that the pause can tell about the person as much as the words do, occupying 40-50\% of the conversation time (Vvedenskaja \& Pavlova, 2012, p. 378).

Furthermore, pauses perform a separating function as well as they are used for speech structuring and increasing the degree of its understanding. Silence at the right moment can be perceived as a sign of confidence which has a strong impact on the listener (Evtihov, 2010, p. 249). Crystal (1997) remarked that pauses can be manipulated for special dramatic effect and help promote the sense of apprehension or understanding (p. 75). Along with the discourse markers the pause acts "to provide time for cognitive refocusing at key transition points of topic development" (Yang, 2004, p. 270).

Describing the role of pauses as well as the ability and need for an actor "to keep a pause", Jurski (1989, pp. 77-78) noted that pauses represent moments of free actions and their self-development. The pause addressed to the audience from the stage, in his opinion, does not give any new information, but at this very moment everything accumulated during the previous acting "is converted in the viewers' souls into a new quality". The pause, being "the viewers' creative time", stimulates their mental activities so that they can reflect upon the unspoken (p. 79).

The uniqueness of a pause was seen by Stanislavski (1954b) in its capability to convey the implied idea which comes from the speaker's subconscious and cannot be clearly expressed verbally. He also noted that the pause stimulates corresponding cognitive processes in the listener's mind, as if continuing the flow of oral speech.

Using the terminology of modern science, to the functional peculiarities of pauses outlined in the above mentioned statements, we can add the following: (1) the direct connection of pauses' generation with the speaker's consciousness, subconscious (preconscious) and unconscious (see Freud, 2013; Klimenyuk, 2010, pp. 207-208; Siegfried 2014, pp. 1-2); (2) the ability of speech pauses' psycho-physiological energy to launch the acts of cognitive thinking in the listener's mind; (3) the latent manipulative subliminal potential of speech pauses. Due to this, the pause, being consciously or unconsciously generated by the speaker's psychic energy, complements oral speech with certain connotations and implications that allow him/her to express thoughts and emotions more clearly.

The said above gives us every reason to believe that the speech pause regarded from the energetic point of view is a focusing element of the logical and semantic orientation of communication. Under the influence of the speaker's emotional energy, the speech pause generates the specific utterance meaning out of a multitude of latent alternative ones, adequately decoded by the recipient. This allows us to consider the pause 
as a specific energetic phenomenon of communication that signals about the level of the speaker's emotional and pragmatic energy, triggering the initiation of cognitive decoding processes in the recipient's psychic sphere.

\subsection{Psycho-energetic classification of speech pauses' properties}

Leaving the subliminal potential of pauses for a while, we will focus on the specificity of their generation by the addresser and decoding by the addressee. As is known (Klimenyuk, 2010, pp. 192-204) in the processes of communication the individual's brain processes, structures and stores external information that differs both in sources and the nature of its transmission media. The author also emphasises (ibid, p. 206) that the impulses, activating the energy and motivation of all individual's speaking-and-thinking and physical activities, originate in the sphere of unconscious, whose psycho-physiological energy ensures the realisation of all thinking processes of emotional and cognitive character.

Proceeding from this, we have assumed that speech pauses, depending on the level of their origin in the addresser's psyche (consciousness, subconscious and unconscious), are realised in communication under the influence of various physical parameters of nervous impulses, whose informational and energetic manifestation is perceived and selectively decoded by neural populations that control the functioning of these levels of the addressee's psyche. In other words, we can infer that pauses, generated by the speaker's consciousness, subconscious or unconscious, are decoded at the corresponding levels of the listener's psyche.

Such understanding of closely interrelated processes of pauses' generation, actualisation and decoding in communication has led us to the necessity to systematise speech pauses according to the criterion of their generation level in the speaker's psyche (Fig. 1). Taking this into account, at the first hierarchical level of the classification of speech pauses' psycho-energetic features we stratified their three enlarged classes, generated by the speaker's consciousness, subconscious and unconscious.

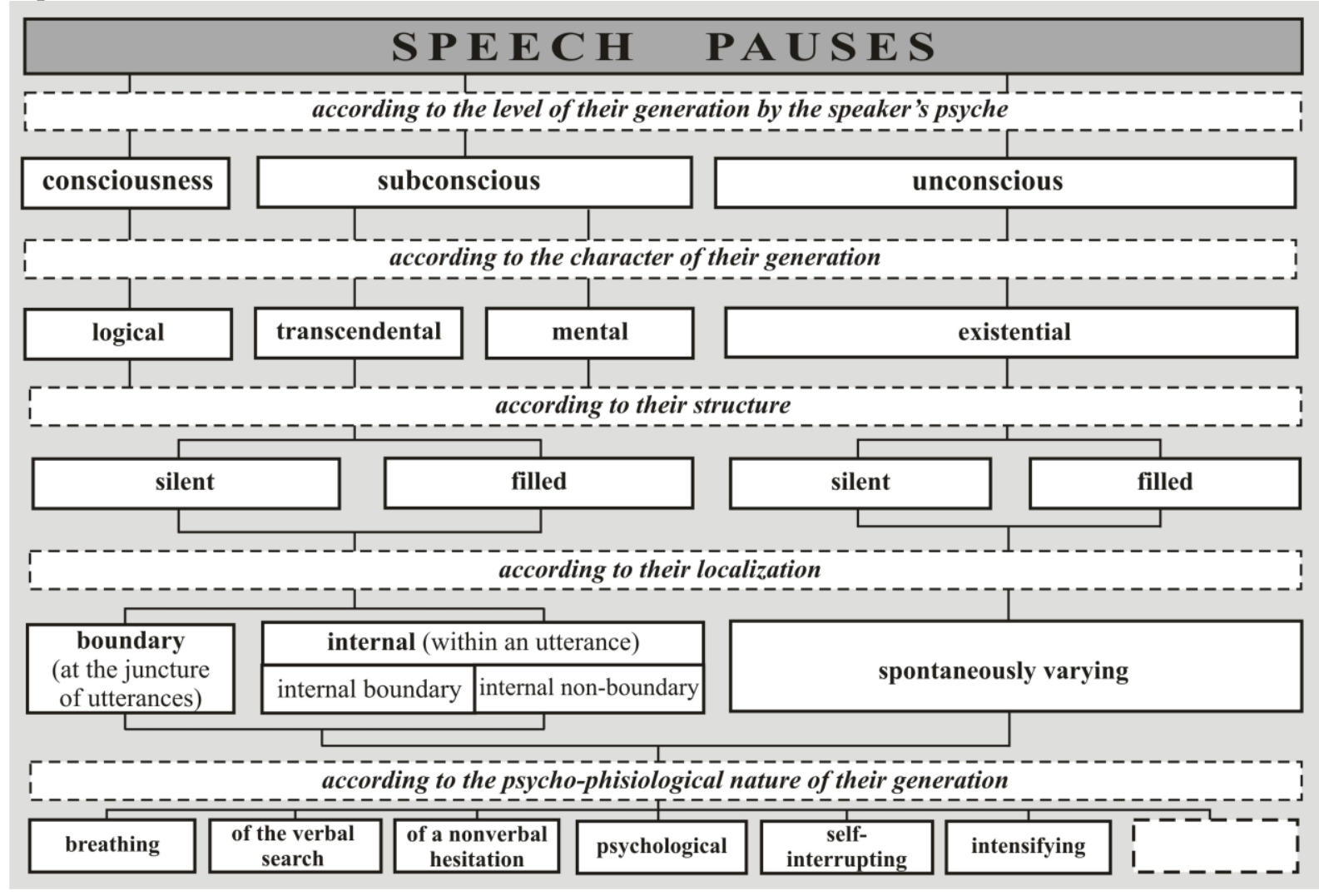

Fig. 1. Classification of psycho-energetic features of speech pauses

Being aware of the importance of further study of the psycho-energetic specificity of speech pauses functioning in communication, in the classification (Fig. 1) we reflected characteristics and nature of their generation. Therefore, as a criterion for organising elements of the classification's second hierarchical level, we adopted the character of pauses' generation. This character, as shown in the papers (Klimenyuk, 2010, pp. 208-213; Klimenyuk \& Kalyta, 2013), is basically determined by those spheres of spiritual being of the 
individual's psyche, in which the processes of thinking were taking place that finally led to the actualisation of a particular type of speech pause.

It is worth emphasising here that the nature of speech pause's generation in its essence may well be defined both by the logical thinking of the individual's consciousness sphere as well as by other kinds of his/her thinking: emotional (inherent to the sphere of existence), emo-rational (occurring in his/her mental sphere), and rational (produced by the transcendental sphere of his/her psyche). It should also be noted that the character of pause's actualisation and those features according to which linguists identify it mainly depend on the sphere of pause's generation.

The analysis of scientific views on the psycho-energetic nature of pauses' generation and their actualisation in communication showed that energetics which produces them essentially depends on the speaker's emotional state. In this regard, the majority of linguists tend to single out the known variety of speech pauses into two enlarged classes, or groups - logical and emotional. It is quite understandable that within the system of general features of speech pauses, the classification of features of logical pauses can be considered as one of its autonomous subsystems. It also seems natural that the second autonomous subsystem should be represented by the classification of the features of emotional speech pauses.

To begin their consideration we are to mention that while reading aloud, emotions are expressed by intonation and psychological pauses (Sternin, 2002, p. 101), which create the emotional interpretation of the text and provide additional shades of its meaning. As it is always associated with the text implication, a psychological pause does not conform to the laws of the text logical division: it can occur at places where logically and grammatically it is impossible to make a pause (Golub \& Nekljudov, 2011, p. 148). Psychological or emotional pauses convey the speaker's feelings, his/her desire to give a special colouring and importance to the word, reveal its meaning which is not expressed verbally, and serve to attract the listener's attention (Tseplitis, 1974, pp. 80-82). According to Stanislavski (1959), if without a logical pause speech becomes illiterate, it becomes dead when there is no psychological pause, comprising a rich inner meaning (p. 87). Emphasising the importance of psychological pauses in speech, he remarks that they are able to tell what is kept back in the verbal context and often function much more intensively, subtly and irresistibly than speech itself. Their wordless conversation can be interesting, informative and persuasive no less than the verbal one.

As for hesitation pauses, they help speakers express their thoughts and find the best, most accurate and clear form of their presentation. Being, in fact, the pauses of contemplation, they can occur anywhere in the utterance and reflect the speaker's fluctuations in the choice of possible language means (Aleksandrova \& Ivanickij, 2003, p. 100; Vvedenskaja \& Pavlova, 2012, p. 379; Swerts, 1998, p. 494). Hesitation pauses can be replaced by any language means: a combination of words, intonation means, for instance, pitch fluctuations, decelerated tempo, increased volume, etc., which help the speaker formulate his/her idea correctly, highlight the word or phrase being the most important and relevant in terms of semantics, thus gaining a special effect in a definite context. Such pauses are sometimes called fading pauses, pauses of meditation, expectation, bewilderment, anxiety (Stanislavski, 1954), hesitation (Swerts, 1998), surprise, embarrassment, anger (Selivanova, 2010, p. 539), uncertainty, doubt (Kalyta 2001, p. 128), pauses of contemplation (Sternin 2002, pp. 89, 114), etc. They can be classified (Aleksandrova \& Ivanickij, 2003, p. 96) according to their qualitative compositional structure into (a) verbal, or filled, i.e. pauses of vocalisation, sound prolongation, of verbal search (lexico-semantic pauses and metatextual commentaries, which by their nature are language or speech units), of incomplete utterances, unintended repetitions, false starts and restarts, and (b) nonverbal: unfilled pauses of hesitation, or paralinguistic pauses.

In communication hesitation pauses perform a number of functions: communicative, phatic, controlling and correcting, masking the speaker's speech difficulties or embarrassment, etc. (Aleksandrova, 2004). At the same time, hesitation pauses can both help the interlocutors or cause speech disturbance in the process of communication.

Analysing the terminological possibility of forming a second autonomous subsystem of general features of speech pauses' classification, it is reasonable to define the discussed above pauses as emotional ones.

As for the structural and localisation hierarchical levels of pauses' classification (see Fig. 1) the system of pauses includes the following types: (a) filled and silent - according to the type of phonation; (b) boundary pauses (pauses at the juncture of utterances) and internal pauses (within an utterance), spontaneously varying as to their localisation in the text; (c) internal boundary (pauses at the juncture of intonation groups) and internal non-boundary pauses according to their localisation within an intonation group.

It should also be mentioned that since the human psychic energy provides the flow of all processes of his/her speaking-and-thinking and thinking-and-speaking activities (Kalyta, 2015, pp. 331-332), we have 
every reason to insert the criterion of psycho-physiological nature of speech pauses' generation into the fifth hierarchical level of the considered classification (Fig. 1). Due to this there appears a possibility of carrying out an interdisciplinary research in order to establish the degree of prevalence in the process of pauses' generation either (1) of the speaker's psychic energy (i.e. from the energy of instincts through the energy of his/her states, emotions and feelings to the energy that provides the work of consciousness) or (2) of physiological energy since the result of pauses' communicative impact conditions not only fluctuations of intonation parameters at the juncture of pause's actualisation, but also the modification of accompanying it paralinguistic means, such as body movements, postures, facial expressions, gestures, etc.

Moreover, we should emphasise as well the practical impossibility of the auditors' clear-cut division of pauses into their two main classes: logical and emotional ones. Besides it seems inexpedient or logically incorrect, in our opinion, to use the notion of "a psychological pause" as an indicator of a particular class, kind, type, group or separate speech pause since any pause, as is known, is produced by the speaker's psychic sphere on the basis of his/her emotion and logic interaction. Therefore, the criterion of the level of pauses' generation by the speaker's psyche (i.e. consciousness, subconscious, unconscious) can be viewed as the most common feature for classifying pauses into three enlarged groups (Fig. 1). Such an approach fully agrees with Stanislavski's statement (1954b) that the pause expresses the implied meaning of that part of the text which emerges not only from the speaker's consciousness, but also from his/her subconscious which does not yield to a definite verbal expression.

However, the results of our preliminary systemic matrix analysis showed the insufficient reliability of links between the elements of the fourth and fifth hierarchical classification levels, often prognosticated and described in linguistic sources. That is why it seems rather premature to consider the problem of an exhaustive classification of psycho-energetic features of pauses as a finally solved one. Nevertheless, proceeding from the generally known laws of scientific knowledge genesis, we can confidently presume that although the mentioned problem has only appeared in all its complexity, it seems to be quite solvable.

We believe that to solve this problem it is enough to expand the possibilities of the given classification (Fig. 1) as a theoretical tool of scientific knowledge by converting it into a systemic matrix. All the elements of the classification were inserted into the left column of this matrix. Into its heading we included the scales of experimentally determined physical parameters of prosodic means that participate in the actualisation of specific types of speech pauses. According to the existing methodological requirements, certain complexes or definite prosodic features, having the dimensions of physical quantities, will perform the role of the target parameters. It seems quite possible, since the instrumental registration of these parameters with the help of a number of modern computer programmes does not pose any difficulties.

Let us examine this issue in more detail. To start with, we will mention some characteristics used in linguistic sources for marking the length of speech pauses: short, long (Viola \& Madureira, 2008, p. 721; Kalyta \& Taranenko, 2010, p. 117), long, agonisingly long, extremely long (Stanislavski, 1954); rather long, fairly long (Stanislavski, 1954a); extra long, dragged on (Stanislavski, 1957); prolonged (Kalyta \& Taranenko, 2010, p. 117); major, minor (Yang, 2004, p. 269), mini-pause (Fopel', 2011); minute-long, infinite, much prolonged, extremely long (Jurski, 1989, pp. 36, 38, 43), etc. On the one hand, we see that these types of pauses should be regarded as a descriptive arsenal of typical image-bearing qualitative characteristics of pauses' duration. On the other hand, it is well known that in experimental studies the real pauses length is traditionally measured in milliseconds as a physical unit of registering stops of phonation in oral communication.

However, thus obtained quantitative evaluation of speech pauses' duration is viewed as necessary but not sufficient for a strictly scientific description of the energetic nature of the processes of their generation, actualisation and decoding. For this evaluation, a researcher should also take into account such quantitatively measured speech parameters as intensity and fundamental frequency, which are generally associated with the speaker's psycho-energetic properties of speech production. Instrumental registration of these parameters with the help of a number of modern computer programmes does not constitute any difficulties.

The problem lies primarily in the fact that, since psycho-energetic phenomena of speech intonation organisation have not been given proper attention so far, the tasks of justifying theoretical assumptions of a relevant experimental phonetic research have not been assigned yet in linguistics.

Thus, it becomes obvious that the nature of pauses' functioning in communication should logically be connected with a dynamic phenomenon of energetic interaction of its EPP with the EPP of the utterance in which it is actualised. Before developing the methodological tools necessary to provide a theoretical basis for this approach, we have to focus on the following argumentations. 
2.3. Methodological tools for determining the level of emotional-and-pragmatic potential of pauses

It is necessary, in the first place, to verify the possibility of a practical instrumental specification of a speech pause's dynamic and energetic characteristics. In this respect, we should consider the statement (Tseplitis, 1974, p. 70) that duration is the only available pause's parameter which can be measured instrumentally. Further on, the author demonstrates the expediency to determine the relative pause duration depending on the speech rate. In other words, Tseplitis (1974), defines the relative pause duration by the number of sounds, syllables, words, etc. which at a certain speech rate could fill a pause (p. 71).

Thus, we are talking about the possibility of normalising the pauses' duration, and, consequently, of their comparison in utterances realised with different tempo. Depending on the assigned tasks, the mentioned normalising can be attributed to any speech segment.

The registration of the obtained pauses' dimensionless characteristics offers the opportunity to pass on to the study of dynamics of interaction and correlation between any of the factors that influence the actualisation of various classes of emotional utterances with the help of similar dimensionless parameters of other components of intonation.

As regards the methodology of normalising the energetic characteristics of a spoken utterance, we have theoretically substantiated on the basis of similarity theory methods the dimensionless quantitative $K$ criterion for the level of the emotional-and-pragmatic potential of utterance actualisation (Kalyta \& Taranenko, 2012a, pp. 476-484), which is calculated by the following equation:

$$
\mathrm{K}=\frac{\mathrm{F}_{0} \times \mathrm{t} \times \mathrm{I}_{0}}{1000 \times \mathrm{I}_{3}}, \quad \text { (1) where: }
$$

$\mathrm{K}$ - criterion for the level of an utterance's EPP actualisation;

$\mathrm{F}_{0}$ - fundamental frequency $(\mathrm{Hz})$

$\mathrm{t}$ - syllable duration (msec.);

$\mathrm{I}_{0}$ - amplitude of $\mathrm{F}_{0}(\mathrm{~dB})$;

$\mathrm{I}_{3}$ - amplitude of $\mathrm{F}_{3}(\mathrm{~dB})$;

1000 - milliseconds to seconds conversion factor.

The physical essence of the obtained dimensionless criterion consists in its ability to characterise the quantitative measure of the level of the utterance's EPP, expressed in terms of dimensional prosodic parameters. Its practical use in the analysis of the results of experimental phonetic studies of various utterances (Kalyta \& Taranenko, 2012, pp. 186-191; Kalyta \& Taranenko, 2012a, pp. 480-482) allowed us to systematise their dimensionless energetic variables according to their three corresponding levels (low, mid and high). Thus, we obtained a new theoretical and methodological tool for comparing not only the EPP of different utterances, but also of such speech segments as syllables, rhythmic groups, words, intonation groups, text fragments and texts.

This opens a possibility for the transition to a theoretical justification of a similar dimensionless criterion in order to evaluate the level of the pause's emotional and pragmatic potential. Let us outline the details of the logic and main points of this study.

\section{Theoretical substantiation of the dimensionless criterion of a pausal jump}

It should be pointed out that to determine the required criterion it is expedient, in our opinion, to use a methodological logic which is common for the substantiation of both a relative pause and a dimensionless criterion for the level of the utterance EPP. The essence of this logic consists in normalising the ratio of absolute values of instrumentally measured quantitative prosodic parameters that characterise the dynamics of change in the utterance EPP within the time of its actualisation.

This approach allows us to avoid the above-mentioned inefficiency of searching for a direct relationship between the pauses' duration and their values, or between their function and position in the utterance. This very approach enables the researcher to reach a higher level of scientific abstraction concerning the stochastic nature of speech production (Klimenyuk \& Kalyta, 2013, pp. 16-25), which can be satisfactorily described by identifying the correlations between the utterances' EPP with their semantic structures. In support of this approach in linguistics there have been made the attempts to explain the relationship between a pause and such phenomena as utterance meaning, analytical and synthetic abilities of human brain, its natural respiratory cycles (Tseplitis, 1978, p. 72), its perlocutionary function (Nadeina, 2003), etc.

It is equally important to remember that a pause, which does not have the EPP proper, is known to be one of the most effective means of realising the subliminal influence on the listener. Therefore, in this case, we rely on the idea that a pause should be considered as a specific energetic phenomenon of communication that, on the one hand, signals about the level of the utterance's emotional-and-pragmatic energy, produced by 
the speaker, and, on the other hand, gives an impetus to the initiation of cognitive decoding processes in the recipient's psychic sphere (Kalyta, 2014, pp. 25-26). Due to the dichotomy of this phenomenon we are able to evaluate the level of the pause's subliminal and communicative impact on the basis of a criterion value of a pausal jump of its EPP at the juncture of speech segments (rhythmic group, intonation group, utterance, text fragment, text), preceding and following the pause.

Summarising the mentioned above methodological assumptions, we can formulate the following conditions of the desired criterion of the EPP of a pausal jump: 1) it must be dimensionless and calculated on the basis of instrumentally measured prosodic parameters having dimensional quantity; 2) it must include psycho-energetic and temporal components. The fulfilment of these conditions will make it possible to objectively describe the dynamics of interaction of the EPP of a pausal jump with the levels of the EPP of any speech segments, adjacent to the pause.

Hence it is evident that as the psycho-energetic component of the utterance actualisation we can consider the difference in the values of the discussed above dimensionless criterion of the EPP level of any speech segments, preceding and following the pause. As to the temporal characteristics of the desired criterion, it is advisable to assume the difference between the values of the rate of speech segments preceding and following the pause.

Then the quotient of the difference between the criteria of the emotional-and-pragmatic levels of the intonation groups adjacent to the pause and the difference in the tempo of these intonation groups will give us the value of the pausal jump of the analysed segment's EPP. Having divided the obtained value by the measured length of a pause (in milliseconds), we will get the dimensionless specific pausal jump of EPP, which directly correlates with the time of a speech segment and dynamics of the speaker's organisation of a speech flow.

The formula defining the specific pausal jump of EPP of the adjacent speech segments, being derived on the basis of the stated above conceptual assumptions and methodological conditions, assumes the following form:

- $\Delta P_{y}-$ the specific pausal jump of EPP;

$$
\Delta P y=\left[\frac{\left(K_{1}-K_{2}\right)}{\left(\frac{L_{1}}{t_{1}}-\frac{L_{2}}{t_{2}}\right)}\right]: t_{p}, \quad \text { (2) where }
$$

- $K_{1}$ - the criterion of the EPP level of a speech segment preceding a pause;

- $K_{2}$ - the criterion of the EPP level of a speech segment following a pause;

- $t_{1}$-duration of a speech segment preceding a pause (msc.);

- $t_{2}$-duration of a speech segment following a pause (msc.);

- $L_{1}$ - the number of sounds in a speech segment preceding a pause;

- $L_{2}$ - the number of sounds in a speech segment following a pause;

- $t_{p}$ - pause length (msc.).

Practical testing of the formula effectiveness was carried out by calculating the results of instrumental measurements with the help of computer programmes for sound processing (Praat, Cool Edit Pro, SpectraLab) in the course of experimental phonetic study of psycho-energetic features of the intonation parameters interaction in three classes of utterances, characterised by different levels of their EPP (high, mid and low).

A fragment of the matrix used for recording the results of instrumental measurements as well as a specific pausal jump of EPP, obtained in accordance with the formula (2), is presented in Table 1.

We have to pay special attention to the fact that in real communication numerical indicators of intonation parameters of speech segments preceding the pause can be both higher and lower in relation to the same parameters measured in the segments following the pause. The physical essence of this fact can be interpreted in the formula (2) by changing the sign of a pausal jump $\left(\Delta P_{y}\right)$, derived with the help of this formula. For instance, if the value of a specific pausal jump of EPP calculated according to the formula has a "minus" sign (for example, -9,74), it shows that the pausal jump is aimed at reducing the impact of the EPP of a speech segment, preceding the pause, upon the one, following it. A "plus" sign in front of a calculated value (for example, 29,52), shows by contrast, that a pausal jump of energy is directed at increasing the influence of the EPP of a speech segment, preceding the pause, upon the one, following it. 
Fragment of the matrix presenting the calculation of a specific pausal jump of the utterance EPP based on the results of instrumental measurements of intonation parameters

\begin{tabular}{|c|c|c|c|c|c|c|c|c|c|c|c|c|c|c|}
\hline \multirow[t]{2}{*}{ № } & \multirow[t]{2}{*}{ The utterance } & \multicolumn{11}{|c|}{ Parameters } & \multicolumn{2}{|c|}{$\begin{array}{c}\text { Specific } \\
\text { Pausal } \\
\text { Jump of } \\
\text { EPP }\end{array}$} \\
\hline & & $t_{1}$ & $\mathbf{t}_{2}$ & $\mathbf{t}_{3}$ & $t p_{1}$ & $t_{2}$ & $\mathbf{K}_{1}$ & $\mathbf{K}_{2}$ & $\mathbf{K}_{3}$ & $\mathbf{L}_{1}$ & $\mathbf{L}_{2}$ & $\mathrm{~L}_{3}$ & $\Delta \mathrm{P}_{1}$ & $\Delta \mathbf{P}_{2}$ \\
\hline \multicolumn{15}{|c|}{ Utterances with a high level of emotional-and-pragmatic potential } \\
\hline 1 & But | Russell, | I don't understand. & 135 & 673 & 1310 & 300 & 216 & 20,6 & 63,57 & 38,45 & 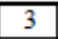 & 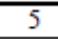 & 14 & \begin{tabular}{|l|}
$-9,74$ \\
\end{tabular} & $-36,57$ \\
\hline 2 & Honey, | why are you so sad? & 528 & 1421 & - & 401 & - & 39,29 & 67,5 & - & 4 & 10 & - & 130,27 & \begin{tabular}{|l|}
- \\
\end{tabular} \\
\hline 3 & Oh, no! || What happened? & 1035 & 919 & - & 198 & - & 119,9 & 49,5 & - & 3 & 9 & - & $-51,53$ & - \\
\hline 4 & \begin{tabular}{|l|l|} 
Don't shop & till you drop! \\
\end{tabular} & 702 & 953 & - & 124 & - & 87,01 & 85,07 & - & 7 & 9 & - & \begin{tabular}{|l|l|}
29,52 \\
\end{tabular} & - \\
\hline \multicolumn{15}{|c|}{ Utterances with a mid level of emotional-and-pragmatic potential } \\
\hline 5 & $\begin{array}{l}\text { Oh, and a jar of peanut butter | and a container of } \\
\text { vanilla yogurt. }\end{array}$ & 265 & 1578 & 1776 & 273 & 166 & 54,85 & 22,83 & 24,29 & 1 & 17 & 25 & $-16,75$ & 2,72 \\
\hline 6 & You don't love me, | Jasmine. & 969 & 575 & - & 047 & - & 32,09 & 34,65 & - & 11 & 6 & - & 59,20 & - \\
\hline 7 & Listen, William, | if you are sick, | I don't think... & 950 & 967 & 826 & 350 & 103 & 18,4 & 33,15 & 28,11 & 9 & 8 & 9 & $-35,12$ & $-19,57$ \\
\hline 8 & No, I made steak & 538 & 874 & - & 279 & - & 53,8 & 34,1 & - & 2 & 8 & - & \begin{tabular}{|l|l|}
2,52 \\
\end{tabular} & - \\
\hline 9 & It's this holiday shopping -I'm ready to drop! & 1692 & 1129 & - & 485 & - & 34,11 & 28,28 & - & 17 & 12 & - & 20,68 & - \\
\hline 10 & $\begin{array}{l}\text { But honey, | I like your company much better than } \\
\text { Hunter's. }\end{array}$ & 781 & 2714 & - & 379 & - & 36,27 & 31,37 & - & 7 & 29 & - & $-7,52$ & - \\
\hline \multicolumn{15}{|c|}{ Utterances with a low level of emotional-and-pragmatic potential } \\
\hline 11 & $\begin{array}{l}\text { You are listening to the BBC world service; I'm } \\
\text { Julian Marshal | with news hour. }\end{array}$ & 3285 & 750 & - & 260 & - & 17,24 & 18,65 & - & 39 & 9 & - & 41,71 & - \\
\hline 12 & $\begin{array}{l}\text { I have to say there are a lot of | unanswered } \\
\text { questions. }\end{array}$ & 1890 & 1278 & - & 154 & - & 19,6 & 19,94 & - & 18 & 15 & - & 0,99 & - \\
\hline 13 & $\begin{array}{l}\text { English intonation. | An introduction. | By John } \\
\text { Wells. }\end{array}$ & 1075 & 771 & 891 & 522 & 976 & 10,25 & 10,58 & 16,65 & 15 & 13 & 9 & 0,22 & $-0,92$ \\
\hline
\end{tabular}

The fragment of the matrix testifies that the obtained "plus" or "minus" sign acts as an objectively registered indicator of the functional orientation of the pausal jump of the speech segments' EPP. The numerical figures of the EPP of a specific pausal jump depend, as it is evident from Table 1, on the difference between the EPP of the adjacent to the pause speech segments and the pause length. The observed correlation between the absolute values of specific pausal jumps of EPP and the levels of EPP of the adjacent segments is not, apparently, rigid, since this correlation also depends on a number of other significant factors accompanying communication, namely: its pragmatic orientation, the situation of communication, the speakers' socio-cultural level and their psychological types, all being traditionally defined by a researcher from the communicative context.

This allows us to assume that in the nearest future linguistics will reach a higher level of scientific knowledge due to the research of psycho-energetic features of emotional utterances actualised by the speaker.

\section{Conclusions}

The importance of obtaining the effect as a result of the implementation of the outlined above systemic methodological approach within the framework of the suggested speech energetic theory lies in the verification of a quantitative criterion that evaluates the levels of psycho-physiological energy consumed by the communicants while generating and decoding pauses. The offered quantitative criterion will, firstly, advance the possibility to classify the energetic properties of emotional utterances, and, secondly, will allow the researcher to make up the speakers' typical psycho-energetic portraits.

The substantiated in the paper conceptual and hypothetical approach gives us the grounds to prognosticate the possibility of obtaining new phonetic knowledge through a systematic study of the relationship between a pausal jump of the emotional-and-pragmatic potential and stable complexes of intonation means that actualise the emotional utterance. Such a relationship provides a subliminal influence of a pause on the processes triggering cognitive mechanisms of the recipient's thinking.

Besides, the performed research makes it possible (1) to create computer programmes for the automated processing of speech pauses' energetic characteristics based on the results of instrumental measurements of the utterance intonation parameters and, thus, (2) to lead to the expansion of scientific concepts of selforganisation and self-development of synergetic processes of speech generation and decoding in the communicants' psychic spheres. 


\section{References:}

Aleksandrova, O. (2004). Rechekommunikativnyj status pauzy kolebanija [The communicative status of a hesitation pause]. Unpublished PhD dissertation, Novgorod State University.

Aleksandrova, O. \& Ivanickij V. (2003). Pauza kolebanija - kompleksnyj fenomen sovremennoj kommunikacii [Hesitation pause as a complex phenomenon of modern communication] Vestnik Novgorodskogo gosudarstvennogo universiteta, 25, 95-101.

Arutjunova, N. (2000). Fenomen molchanija [Phenomenon of silence] In N. Arutjunova (Ed.), Jazyk o jazyke [The language about language] (pp.417-436). Moscow: Jazyki russkoj kul'tury.

Crystal, D. (1997). The Cambridge Encyclopedia of Language. Cambridge: Cambridge University Press.

Evtihov, O. (2010). Psihologija upravlenija personalom: teorija $i$ praktika [Psychology of the personnel management]. St. Petersburg: Rech'.

Fopel', K. (2011). Jenergija pauzy. Psihologicheskie igry i uprazhnenija [Pause's energy. Psychological games and exercises]. Moscow: Genezis.

Freud, S. (2013). The Ego and the Id. Kindle edition.

Golub, I., \& Nekljudov, V. (2011). Russkaja ritorika i kul'tura rechi [Russian rhetoric and speech culture]. Moscow: Logos.

Gooskens, Ch. \& Bezooijen, R. van. (2014). The effect of pause insertion on the intelligibility of Danish among Swedes. In J. Caspers, Y. Chen, W. Heeren, J. Pacilly, N. O. Schiller \& E. van Zanten (Eds.), Above and Beyond the Segments: Experimental linguistics and phonetics (pp. 96-108). Amsterdam/Philadelphia: John Benjamins Publishing Company. https://doi.org/10.1075/z.189.08goo

Jarceva, V. (Ed.). (1990). Lingvisticheskij jenciklopedicheskij slovar' [Linguistic encyclopaedic dictionary]. Moscow: Soviet Encyclopaedia.

Jurski, S. (1989). Kto derzhit pauzu [Who holds a pause]. Moscow: Iskusstvo.

Kalyta, A. (2001). Fonetichni zasobi aktualizacii smislu anglijs'kogo emocijnogo vislovljuvannj [Phonetic means actualising the meaning of an English emotional utterance]. Kyiv: Publishing centre of Kyiv National Linguistic University.

Kalyta, A. (2014). Psiho-energetika pauz zvuchashhej rechi [Psycho-energetics of speech pauses]. Naukovi zapiski. Serija: Filologichni nauki (movoznavstvo), 127, 24-34.

Kalyta, A. (2015). Phonetic studies from the perspective of an energetics approach. In A. Bondaruk \& A. Prazmowska (Eds.), Within language, beyond theories (Volume I): studies in theoretical linguistics (pp. 322-336). Cambridge: Cambridge Scholars Publishing.

Kalyta, A. \& Taranenko, L. (2010). Concise Dictionary of Phonetic Terms. Ternopol': Pidruchniki i posibniki.

Kalyta, A. \& Taranenko, L. (2012). Perceptivna j instrumental'na ocinki emocijno-pragmatichnogo potencialu vislovlen' [Auditory and instrumental evaluation of the utterance emotional-and-pragmatic potential]. Naukovij visnik Volins'kogo nacional'nogo universitetu imeni Lesi Ukraïnki. Serija: Filologichni nauki: Movoznavstvo, 24 (249), 186-191.

Kalyta, A. \& Taranenko, L. (2012a). Kriterij urovnja aktualizacii jemocional'no-pragmaticheskogo potenciala vyskazyvanija [Criterion of the utterance emotional-and-pragmatic potential level]. Naukovi zapiski. Serija: Filologichni nauki (movoznavstvo). 105(1), 476-84.

Klimenyuk, A. (2010). Znanie, poznanie, kognicija [Knowledge, intellection, cognition]. Ternopol': Pidruchniki i posibniki.

Klimenyuk, A. \& Kalyta A. (2013). Optimizacija kommunikativnogo vozdejstvija [Optimising the communicative influence] Naukovi zapiski. Serija: Filologichni nauki (movoznavstvo), 118, 16-25.

Lunacharskij, A., ed. (1934). Literaturnaja jenciklopedija [Literary Encyclopaedia] (Vol. 8). Moscow: Soviet Encyclopaedia.

Nadeina, T. (2003). Prosodicheskaja organizacija rechi kak faktor rechevogo vozdejstvija [Prosodic organisation of speech as a factor of speech influence]. Unpublished Doctoral dissertation, Russian Academy of Science.

Selivanova, O., (Ed.). (2010). Lingvistichna enciklopedija [Linguistic encyclopaedia]. Poltava: Dovkillja-K.

Stanislavski, K. (1954). Moja zhizn' v iskusstve [My life in art]. In Sobranie sochinenij v 8-mi tomah [Collected edition of works in 8 volumes] (Vol. 1). Moscow: Iskusstvo.

Stanislavski, K. (1954a). Rabota aktera nad soboj. Chast I [The work of actor upon himself. Part I]. In Sobranie sochinenij $v$ 8-mi tomah [Collected edition of works in 8 volumes] (Vol. 2, pp.). Moscow: Iskusstvo.

Stanislavski, K. (1954b). Rabota aktera nad soboj. Chast II [The work of actor upon himself. Part II]. In Sobranie sochinenij v 8-mi tomah [Collected edition of works in 8 volumes] (Vol. 3). Moscow: Iskusstvo.

Stanislavski, K. (1957). Rabota aktera nad rol'ju [The actor's work on the role]. In Sobranie sochinenij v 8-mi tomah [Collected edition of works in 8 volumes] (Vol. 4). Moscow: Iskusstvo.

Stanislavski, K. (1959). Stat'i. Rechi. Otkliki. Zametki. Vospominanija (1917-1938) [Articles. Speeches. Reactions. Remarks. Reminiscences. (1917-1938)] In Sobranie sochinenij v 8-mi tomah [Collected edition of works in 8 volumes] (Vol. 6). Moscow: Iskusstvo.

Siegfried, W. (2014). The Formation and Structure of the Human Psyche Athene Noctua: Undergraduate Philosophy Journal, 2, 1-3. Sternin, I. (2002). Ritorika [Rhetoric]. Voronezh: Izd-vo "Kvarta".

Swerts, M. (1998). Filled pauses as markers of discourse structure. Journal of Pragmatics, 30, 485-96. https://doi.org/10.1016/s03782166(98)00014-9

Tseplitis, L. (1974). Analiz rechevoj intonacii [Speech intonation analysis]. Riga: Zinatne.

Viola, I.C. \& Madureira, S. (2008, May, 6-9). The roles of pause in speech expression In Proceedings of the Fourth Conference on Speech Prosody (pp.721-724). Campinas, Brazil.

Vvedenskaja, L. \& Pavlova, L. (2012). Ritorika i kul'tura rechi [Rhetoric and speech culture]. Rostov-on-Don: Feniks.

Yang, L. (2004). Duration and Pauses as Cues to Discourse Boundaries in Speech. In B. Bel \& I. Marlien (Eds.), Proceedings of the 2nd International Conference on Speech Prosody (pp. 267-270). Nara, Japan. 